\title{
APLIKASI TEORI ISNAD CUM MATN HARALD MOTZKI DALAM HADIS MISOGINIS PENCIPTAAN PEREMPUAN
}

\author{
Faisal Haitomi \\ Universitas Islam Negeri Sunan Kalijaga Yogyakarta \\ J1. Marsda Adisucipto, Yogyakarta, 55281 \\ E-mail: faisalhaitomi@gmail.com \\ Muhammad Syachrofi \\ ${ }^{2}$ Universitas Islam Negeri Sunan Kalijaga Yogyakarta \\ Jl. Marsda Adisucipto, Yogyakarta, 55281 \\ E-mail: msyachrofi93@gmail.com
}

DOI: http:dx.doi.org/10.32505/al-bukhari.v3i1.1432

Submitted: 2020-02-05 | Revised: 2020-03-03| Accepted: 2020-03-19

\begin{abstract}
Harald Motzki is one of the orientalists who study the hadith objectively. One of Motzki's theories in studying hadith is isnad cum matn. This theory is a method in searching the history of hadith and combining aspects of isnad and matan as well as the Common Link theory which was popularized by Juynbol. In this article the author uses misogynistic traditions about the creation of women, bearing in mind that these traditions are often used as a reason to legitimize discrimination against women. The author found that misogynistic traditions about the creation of women were delivered by the Prophet himself, and at the same time, the Prophet also became the common link of these hadiths. In Mysoginy perspectives raditions or more specifically traditions that talk about the creation of women from ribs are also authentic from the Prophet and are delivered in two versions, namely the long version and the short version, which are then recorded in several hadith books.
\end{abstract}

Keywords: Hadith, Isnad Cum Matn, Motzki

\begin{abstract}
Abstrak
Harald Motzki adalah salah satu di antara orientalis yang mengkaji hadis secara objektif. Salah satu teori Motzki dalam mengkaji hadis yaitu Isnad cum matn. Teori ini merupakan sebuah metode dalam mencari kesejarahan hadis dan mengkombinasikan aspek isnad dan matan serta teori Common link yang di populerkan oleh Juynbol. Di dalam artikel ini penulis menggunakan hadis-hadis misoginis tentang penciptaan perempuan, mengingat hadis ini sering dijadikan alasan untuk melegitimasi perlakuan diskriminasi terhadap perempuan. Penulis menemukan bahwa hadis-hadis misoginis tentang penciptaan perempuan disampaikan oleh Nabi sendiri, dan dalam waktu yang bersamaan, Nabi juga menjadi common link dari hadis tersebut. Secara matan hadis misoginis atau lebih khusus hadis yang berbicara tentang penciptaan perempuan dari tulang rusuk juga otentik dari Nabi serta disampaikan dalam dua versi yaitu versi panjang dan versi pendek, yang kemudian di catat dalam beberapa kitab hadis.
\end{abstract}

Kata Kunci: Hadis, Isnad Cum Matn, Motzki 


\section{Pendahuluan}

\section{Berbicara}

masalah

perempuan dan kaitan dengan teks keagamaan memang selalu menarik perhatian banyak kalangan baik dari sarjana muslim maupun sarjana Barat. Pasalnya dalam banyak literatur, perempuan seolah dijadikan makhluk nomor dua setelah laki- laki tak terkecuali di dalam hadis. Hal ini kemudian diperparah dengan pemahaman yang literer terhadap teks tersebut yang berimplikasi terhadap semakin terpojoknya posisi perempuan dalam semua ruang. ${ }^{1}$

$$
\text { Salah satu hadis yang }
$$
dianggap misoginis (membenci perempuan) adalah hadis tentang penciptaan perempuan. Nurun Najwah di dalam disertasinya menjelaskan bahwa hadis penciptaan perempuan oleh mayoritas ulama difahami secara leksikal, sehingga ini berimbas terhadap posisi perempuan yang

\footnotetext{
${ }^{1}$ Muh. Muhtador, “ Memahami Hadis Misoginis Dalam Perspektif Hermeneutika Produktif Hans Gadamer" di dalam Jurnal Diya al-Afkar Vol.6 No. 2, Desember 2018, 257-259.
}

dianggap sebagai kelompok kedua setelah laki-laki. $^{2}$

Fatimah Mernissi salah satu sarjana yang sangat gencar dalam mengkritik hadis-hadis yang dianggap misoginis juga menyatakan keragu-raguannya terhadap hadis ini sebagai sesuatu yang datang dari Nabi. ${ }^{3}$ Di dalam artikel ini penulis mencoba untuk menelaah hadis penciptaan perempuan untuk melihat apakah hadis tersebut dari Nabi atau bukan, seperti yang disangkakan oleh banyak kalangan seperti Fatimah Mernissi di atas.

Dalam menelaah hadis tersebut penulis menggunakan teori Isnad cum matn yang ditawarkan oleh Harald Motzki (seorang orientalis yang objektif dalam mengkaji hadis). Kajian ini hanya terbatas pada dating (penanggalan)

\footnotetext{
${ }^{2}$ Nurun Najwah, "Rekonstruksi Pemahaman Hadist- hadits Perempuan", Disertasi Doctor IAIN Sunan Kalijaga Yogyakarta 2004, hlm 10-15. Lihat juga Fatima Mernissi “ Wanita Dalam Islam"( Bandung: Pustaka, 1414 H/ 1994 M), 6279.

${ }^{3}$ Dadah, " Metode Kritik Matan Hadis Misoginis Menurut Fatimah Mernissi, Diroyah: Jurnal ilmu Hadist 3, 1 (September) 2018, 11-18.
} 
untuk melihat apakah teks tersebut asli dari Nabi serta kapan ia di ucapkan, sesuai dengan apa yang telah dirumuskan oleh Motzki.

\section{Biografi Harald Motzki}

Nama lengkapnya adalah Harald Motzki. Lahir di Jerman tahun 1948. Dalam rentang waktu sepuluh tahun ia menyelesaikan pendidikannya dari tingkat strata satu sampai doctoral. Pada tahun 1974-1978, ia mendapat gelar M.A dan Ph.D di Bonn University.

Tahun 1979-1983 ia menjadi anggota peneliti di Institute of Historical Anthropplogy, dan di waktu yang sama ia juga menjadi dosen dalam Islamic Studies and Arabic di University of Bremen. Tahun 1983-1989 ia menjadi asisten professor di Institute of History and Culture of The Middle East at the University of Hamburg Jerman, dan pada tahun 1989 ia meraih kualifikasi pasca doctoral dengan habilitation $^{4}$ yang berjudul Die Anfange der Islamischen

${ }^{4}$ Habilitation adalah sebuah penelitian yang dilakukan setelah program doctoral yang biasanya di dunia barat bisa memakan waktu 5-7 tahun.
Jurisprudenz, Ihre Entwicklung in Mekka bis zur Mitte des Jahrhunderts. ${ }^{5}$

Karya yang dihasilkan di antaranya: Der Fiqh des-zuhri : die Quellenproblematik, The Jurisprudence of Ibn Syihab azZuhri, The Musannaf of 'Abd AlRazzaq Al-Sana'ani as a Source of Authentic ahadith of the First Century. Ihre Entwicklung in Mekka bis zur Mitte des 2./8. Jahrhunderts, yang merupakan karyanya yang paling fenomenal karena mengkritik teori para pendahulunya yaitu Ignaz Goldziher dan Joseph Shacht. ${ }^{6}$

\section{Pengertian Isnad Cum Matn}

Isnad cum matn merupakan sebuah metode dalam mencari kesejarahan hadis dengan mengkombinasikan aspek isnad dan matan. Metode ini bekerja untuk menelaah jalur-jalur periwayatan

\footnotetext{
${ }^{5}$ Rona Rasyidaturrabi'ah, Hadis Nikah Mut'ah (Studi Aplikatif Isnad Cum Matn ), Skripsi Fakultas Ushuluddin UIN Sunan Kalijaga Yogyakarta, 20.

${ }^{6}$ https://www.academia.edu/29873 602/Otentisitas_Hadis_Penelusuran_Harald Motzki terhadap Mushannaf_Abdul_Raz zq, diakses pada tanggal 4 April 2019.
} 
maupun teks matn hadis, sehingga kesejarahan hadis yang dimaksud adalah kesejarahan dalam periwayatan hadis itu sendiri. Dengan metode ini, sanad-sanad dari versi tersebut diperiksa dengan membandingkan teks-teks dari versi-versi tersebut pada level periwayatannya yang berbeda. Metode Isnad cum matn bukan untuk membandingkan sebuah matn dengan Al-Qur'an, hadis sahih, dan fakta sejarah, tetapi metode ini akan menganalisa sejauhmana riwayat teks seorang perawi melenceng atau berbeda secara tekstual dengan riwayat yang lain.

Adapun langkah-langkah dari metode isnad cum matn, adalah sebagai berikut: pertama, mengumpulkan hadis yang mempunyai tema yang sama. Kedua, membuat pohon sanad dari keseluruhan sanad hadis yang telah dikumpulkan serta menentukan common link dan partial common link dari pohon sanad. Ketiga, mengecek matan dari setiap sanad yang telah dikumpulkan untuk dikonfirmasi apakah antara satu sanad dengan sanad yang lain memiliki kesamaan. Keempat, jika terdapat korelasi, matan yang asli dari hadis tersebut harus dimunculkan untuk melihat siapa yang bertanggung jawab atas tersebarnya sebuah hadis.

\section{Tujuan Dating Hadis}

Sarjana Barat yang pada umumnya mereka memandang bahwa hadis adalah bagian dari sejarah, mereka mencoba mencari pengetahuan dalam hadis tersebut untuk menemukan apa yang sebenarnya terjadi. ${ }^{7}$

Dalam melakukan dating hadis melalui metode isnad cum matn, banyak ditemukan berbagai istilah yang dibuat oleh Barat dalam konteks kajian hadis di antaranya adalah common link $^{8}$ partial common link, ${ }^{9}$ singel strend, ${ }^{10}$

\footnotetext{
${ }^{7}$ Rona Rasyidaturrabi'ah, Hadis Nikah Mut'ah (Studi Aplikatif Isnad Cum Matn), Skripsi Fakultas Ushuluddin UIN Sunan Kalijaga Yogyakarta, 23.

${ }^{8}$ common link adalah orang yang dianggap bertanggung jawab atas tersebarnya hadis hingga ke para mukharrij hadis common link dianggap sebagai pemalsu hadis. Lihat Ali Masrour, Toeir Common link G.H.A Juynbool Melacak Akar Kesejarahan Hadits Nabi, (Bandung: LKis, 2010), xxii-xxiii.

${ }^{9}$ Partial common link adalah periwayat hadis yang menjadi common link untuk sebagaian isnad. biasanya partial
} 
diving strand, ${ }^{11}$ inverted partial common link. ${ }^{12}$

Menurut Motzki common link bukanlah orang yang bertanggung jawab atas penyebaran suatu hadis, seperti yang disangkakan oleh Juynboll dan Schaht. Motzki menjelaskan bahwa common link adalah penghimpun hadis yang sistematis pertama yang merekam dan meriwayatkan ke dalam kelas-kelas murid regular dan dari kelas itulah sebuah sistem terlembaga dan berkembang. ${ }^{13}$

common link ini adalah murid dari common link yang sesungguhnya. Adapun syarat untuk menjadi common link dan partial common link adalah harus mempunyai dua orang atau lebih murid dan murid tersebut harus pula mempunyai dua orang atau lebih murid begitu seterusnya sampai kepada orang terakhir yang menerima hadits.

${ }^{10}$ Single strand adalah sanad yang hanya terakhir.mempunyai satu jalur sampai ke periwayat terakhir.

${ }^{11}$ Diving strand adalah periwayat yang tiba- tiba langsung bertemu dengan orang yang berada dibawah common link tanpa terlebih dahulu melewati common link. biasanya ini terjadi pada periwayat tingkat tabi' tabi'in yang langsung menerima dari sahabat tanpa melalui tabi'in.

${ }^{12}$ Periwayat yang menerima informasi sebuah hadis dari lebih dari seorang guru dan kemudian ia hanya menyampaikan kepada seorang murid.

${ }^{13}$ Kamarudin Amin, Menguji Kembali Keakuratan Metode Kritik Hadits, (Jakarta : Mizan Media Utama, 2009 ), viii.
Hadis Asal Penciptaan

Perempuan.

Penulis menemukan hadis ini terdapat di dalam beberapa kitab, Sahih Bukhari, Sahih Muslim, Musnad Abu Ya'la, Sunan Kubra Al-Baihaqi, Mushannaf Ibnu Abi Syaibah, Sunan Kubra An-Nasa'i, Musnad Al- Bazzar, Mukhtasat Nashih Fi Tahzib Kitab Al- Jami', Musnad Ahmad bin Hanbal, Sunan Ad- Darimi, Mawarid Al- Zaman Ibnu Hibban, Musnad Humaidi, Mustakhraj Abu 'Awanah, Musnad Al-Haris.

Sahih Bukhari

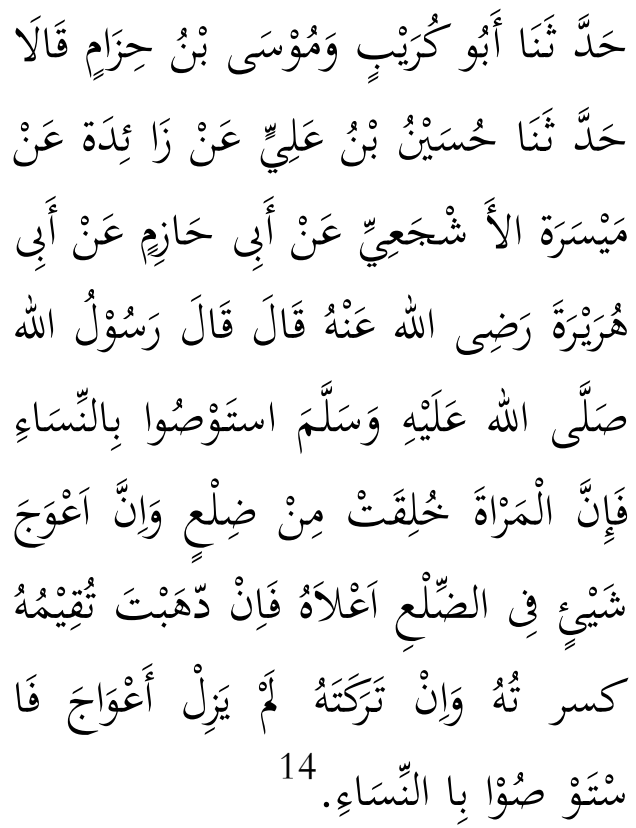

${ }^{14} \mathrm{Abū}$ 'Abdillāh Muhammad bin Ismā‘îl ibn Ibrāhīm ibn Mughīrah al Ju’fi 
Telah bercerita kepada kami Abu Kuraib dan Musa bin Hizam keduanya berkata, telah bercerita kepada kami Husain bin 'Ali dari Za'idah dari Maisarah al-Asja'i dari Abu Hazim dari Abu Hurairah r.a berkata, Rasulullah SAW bersabda: "Nasehatilah para wanita karena wanita diciptakan dari tulang rusuk yang bengkok, dan yang paling bengkok dari tulang rusuk adalah pangkalnya, jika kamu mencoba untuk meluruskannya maka dia akan patah namun bila kamu biarkan maka dia akan tetap bengkok. Al-A'raj telah menambahkan jika kamu hendak bersenang-senang dengannya, kamu dapat bersenang-senang dengannya dan dia tetap bengkok, maka berwasiatlah kepada wanita dengan kebaikan."

حدثنا عبد العزيز بن عبد الله قال حدثني مالك عن أبي الزنّاد عن الأعرج عن أبي هريرة قال : قال رسول الله صلّى الله عليه وسلّم استَوْصُوا بِالنَِّاعِ

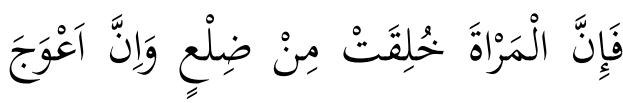

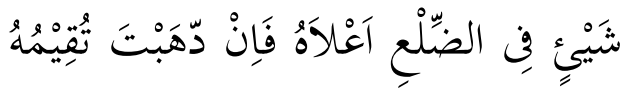
كسر تُهُ وَاِنْ تَرَكَتَهُ لَجْ يَزِلْ أَعْوَاجَ. 15

al-Bukhārī, Jam'u al-Șahịh (T.t : Darul Tuqi Al Najah, 1422 H), Juz 4, 133.

${ }^{15}$ Muhallab ibn Abī Safrah alTamimī al-Mālikī al-Andalusī,. Mukhtasiar al-Nasih fì Tahzīb al-Kitāb Jāmi' al-Sahịh, Muhaqqiq Aḥmad Ibn Faris al-Salumī
Telah menceritakan kepada kami Abdullah ia berkata; telah menceritakan kepadaku Malik dari Abi Zinnad dari Al A'raj dari Abu Hurairah ia berkata : Rasulullah saw bersabda: "Nasehatilah para wanita karena wanita diciptakan dari tulang rusuk yang bengkok, dan yang paling bengkok dari tulang rusuk adalah pangkalnya, jika kamu mencoba untuk meluruskannya maka dia akan patah namun bila kamu biarkan maka dia akan tetap bengkok."

\section{Sahih Muslim}

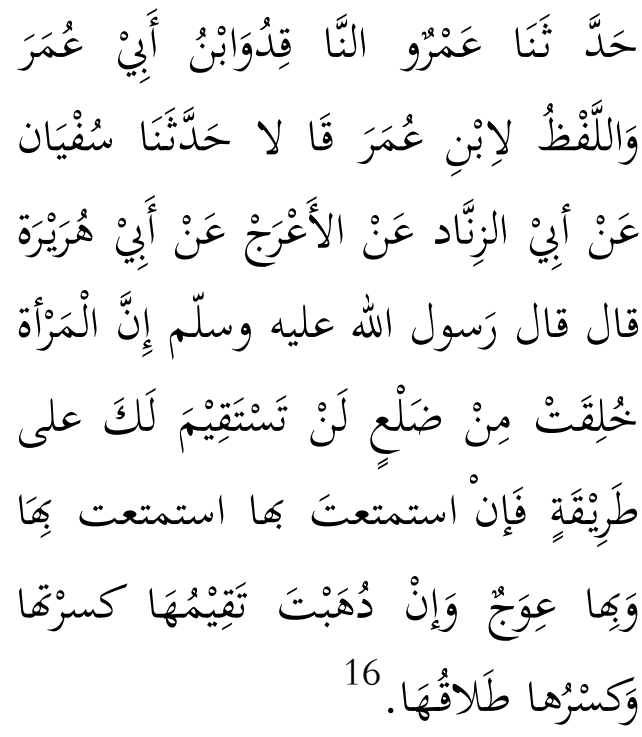

Telah menceritakan kepada kami Amr Al-Naqid dan Ibnu Abu Umar sedangkan lafaznya dari Ibnu Abu Umar, keduanya berkata, telah menceritakan kepada kami

(Riyadh : Dārul Tauhīè, Dārul Ahli Sunnah, 1430 H / 2009 M ), Juz 2, 413.

${ }^{16}$ Abū Husain Muslim bin Hajjāj al-Qusyairy al-Naysābūrī, Șaḥịh Muslim (Beirūt: Dār al-Kitāb al-'Alamiyyah 1412 H / 1991 M ), Juz 2, 1091. 
Sufyan dari Abu al-Zinad dari Al-A'raj dari Abu Hurairah dia berkata Rasulullah saw bersabda: " Sesungguhnya seorang wanita diciptakan dari tulang rusuk, dan tidak dapat kamu luruskan dengan cara bagaimanapun, jika kamu hendak bersenangsenang dengannya, kamu dapat bersenang-senang dengannya dan dia tetap bengkok, namun jika kamu berusaha meluruskannya, niscaya dia akan patah, dan mematahkannya adalah menceraikannya.

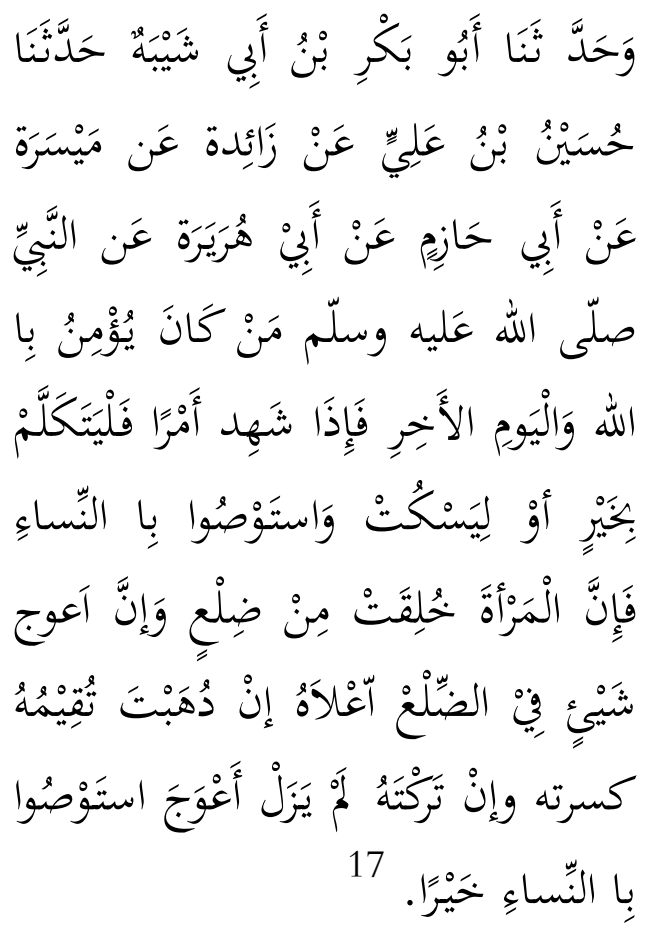

Telah menceritakan kepada kami Abu Bakar bin Abi Syaibah telah menceritakan kepada kami Husain bin Ali

${ }^{17}$ Abū Husain Muslim bin Hajjāj al-Qusyairy al-Naysābūrī, Șaḥ̄h Muslim (Beirūt: Dār al-Kitāb al-'Alamiyyah 1412 H / 1991 M ), Juz 2, 1091. dari Za'idah dari Maisarah dari Abu Hazim dari Abu Hurairah dari Nabi saw beliau bersabda : “ Barangsiapa yang beriman kepada Allah dan hari akhir, kemudian ia menyaksikan suatu peristiwa, hendaklah dia berbicara dengan baik atau diam, dan berwasiatlah kepada wanita dengan kebaikan, karena sesungguhnya dia diciptakan dari tulang rusuk, dan bagian yang paling bengkok adalah tulang rusuk paling atas, jika kamu berusaha untuk meluruskannya, niscaya akan patah, jika kamu membiarkannya, dia akan senantiasa bengkok, maka berwasiatlah kepada wanita dengan kebaikan.

\section{Musnad Ahmad bin Hanbal}

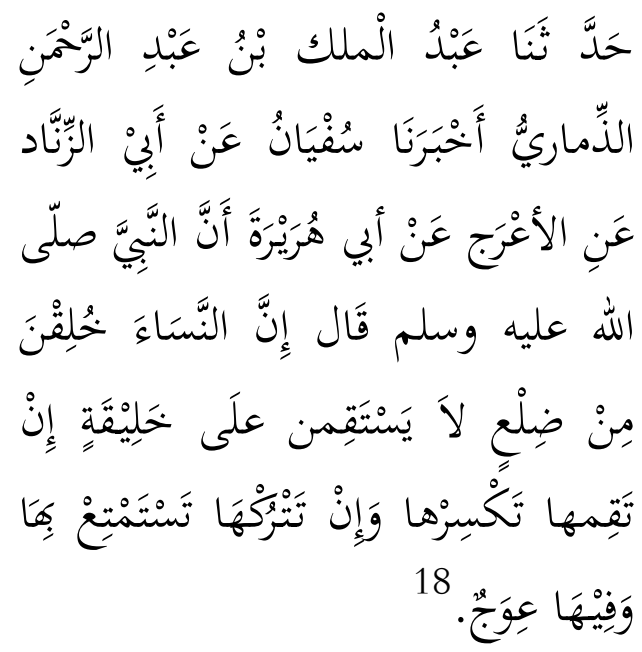

Telah menceritakan kepada kami Abdul Malik bin

${ }^{18} \mathrm{Abu}$ Abdullah Ahmad bin Hanbal bin Hilal bin Asad al- Zuhaily AsySyaibani, Musnad Ahmad bin Hanbal dalam CD ROM al- Maktabah alSyamilah, Edisi 2.11 
Abdurrahman Adz Dzimari, dia berkata, telah mengabarkan kepada kami Sufyan dari Abu Zinnad dari Al A'raj dari Abu Hurairah dia berkata, Rasulallah saw bersabda : "Sesungguhnya para wanita itu di ciptakan dari tulang rusuk, ia tidak bias lurus dalam penciptaannya, jika engkau luruskan maka engkau akan mematahkannya, dan jika engkau biarkan maka ia akan berlaku seperti itu terus, padahal pada diri mereka terkandung unsur bengkok.

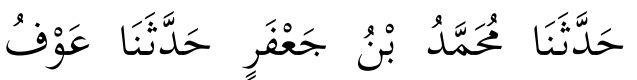

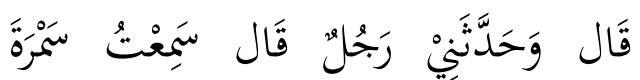

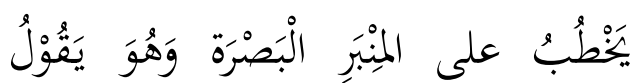
سَمَعْتُ رَسُول الله صَلَّى الله علَيْه وسلَّم

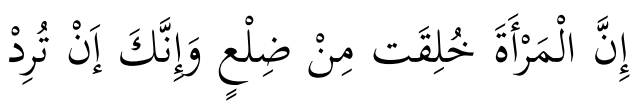

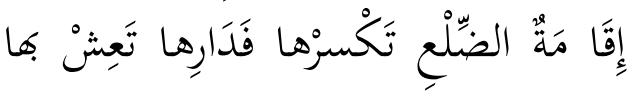

Telah menceritakan kepada kami Muhammad bin Ja'far telah menceritakan kepada kami 'Auf ia berkata, telah menceritakan kepada kami seseorang ia berkata aku mendengar Samurah berkhutbah di mimbar Basrah

19 Abū 'Abdillāh Ahmad bin Muhammad bin Ahmad bin Hilal bin Asad bin al-Syabaini, Musnad Ahmad bin Hanbal (T.t: Muassah Al Risalah, T.t ), Juz 33, 283. ia berkata " aku mendengar Rasulullah saw bersabda: "Sesungguhnya wanita itu diciptakan dari tulang rusuk kiri, jikalau engkau hendak meluruskan tulang rusuk itu, maka engkau akan mematahkannya tapi jika engkau membiarkannya maka ia akan tetap melengkung.

\section{Sunan Ad-Darimi}

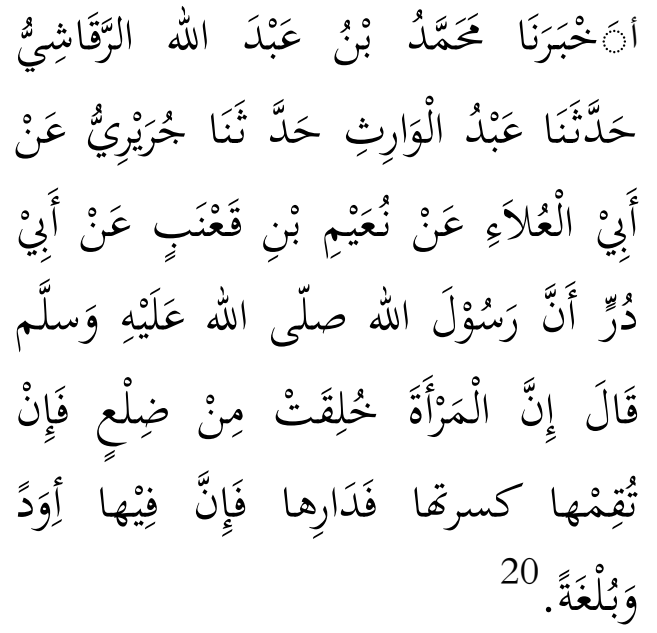

Telah mengabarkan kepada kami Muhammad bin Abdillah Al-Raqasyi ,telah menceritakan kepada kami Abdul Warits, telah menceritakan kepada kami Al Jurair dari Abu Al 'Ala dari Nu'aim bin Qa'nab dari Abu Dzar bahwa Rasulullah saw bersabda: "Sesungguhnya seorang wanita diciptakan dari tulang rusuk, apabila engkau meluruskannya maka engkau akan mematahkannya, maka bersikaplah lembut kepadanya, sesungguhnya

${ }^{20}$ Abū Muhammad 'Abdullāh ibn 'Abdurrahmān ibn Faḍil ibn Bahram alDārimī, Sunan al-Dārimī (T.t: Darul Mughni, 1421 H /2000 M ), Juz 3, 1425. 
terdapat kebengkokan dan kehidupan yang sepadan.

\section{Sunan Kubra al-Baihaqi}

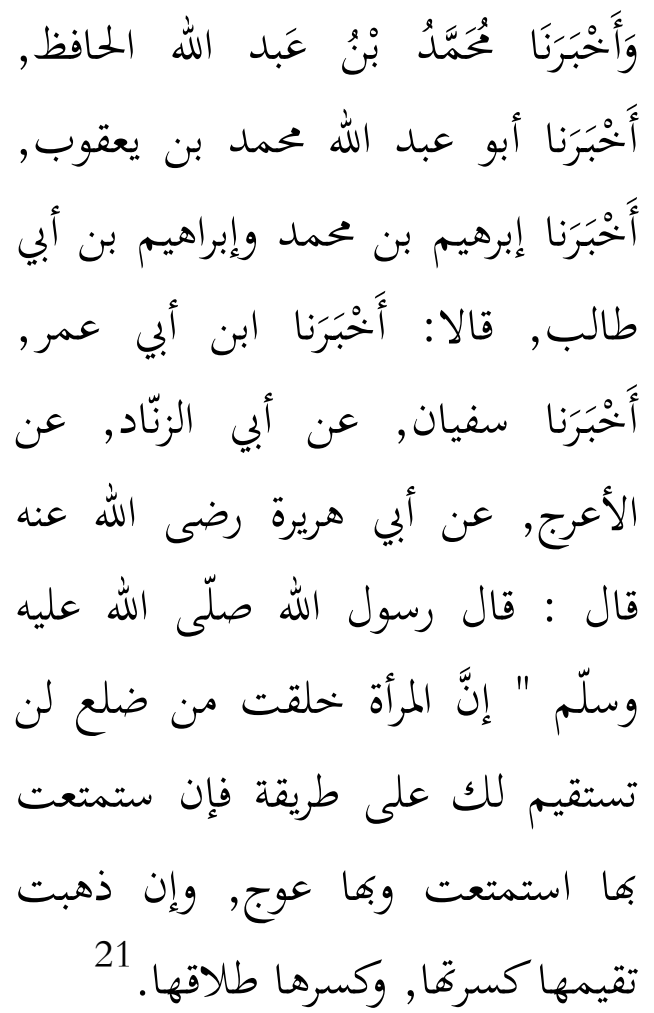

Telah mengabarkan kepada kami Muhammad bin Abdulllah al-Hafiz, telah mengabarkan kepada kami Abdullah Muhammad bin Ya'qub, telah mengabarkan kepada kami Ibrahim bin Muhammad dan Ibrahim Abi Thalib, ia berkata : telah mengabarkan kepada kami Ibnu Abi Umar, telah mengabarkan kepada kami Sufyan, dari Abi Zinnad, dari Al-A'raj, dari Abu Hurairah beliau berkata: telah bersabda

${ }^{21}$ Abū Bakar Ahmad bin Husain ibn 'Ali al-Baihaq̄i, Sunan Al-Kubrā alBaihaq̄ (Beirūt: Dār al-Kitāb alAlamiyyah, 1424 H/ 2003 M ), Juz 7, 481.
Rasulallah

saw: “

Sesungguhnya wanita diciptakan dari tulang rusuk, dan tidak dapat kamu luruskan dengan cara bagaimanapun, jika kamu hendak bersenang-senang dengannya, kamu dapat bersenang-senang dengannya dan dia tetap bengkok, namun jika kamu berusaha meluruskannya, niscaya dia akan patah, dan mematahkannya adalah menceraikannya.

أخبرنا أبو عبد الله الحافظ, أخْبَرَنا أبو عبدالله بن محمد بن يعقوب, أَخْبَرَنا إبراهيم بن إسحاق, أَخْبَرَنا هرون بن بن بن بن

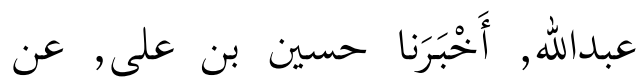
زائدة, عن ميسرة, عن أبي حازم, عن أبي هريرة رضى الله عنه قال : قال رسول الله صلّى الله عليه وسلّم : " من كان يؤ من با الله واليوم الأخر فإذا شهد أمرا فليتكلم بخير أو ليسكت, استوصوا با النساء خيرا فيان المرأة خلقت من ضلع وإن أعوج شئ من الضلع أعلاه, فإن ذهبت تقيمه كسرته, وإن تركته لم يزل أعوج.

${ }^{22}$ Abū Bakar Ahmad bin Husain ibn 'Ali al-Baihaq̄i, Sunan Al-Kubrā alBaihaq̄i (Beirūt: Dār al-Kitāb alAlamiyyah, 1424 H/ 2003 M ), Juz 7, 480481 . 
Telah mengabarkan kepada kami Abu Abdullah Al-Hafidz, telah mengabarkan kepada kami Abu Abdallah ibn Muhammad ibn Ya'qub, telah mengabarkana kepada kami Ibrahim bin Ishaq, telah mengabarkan kepada kami Harun ibn Abdillah, telah mengabarkan kepada kami Husain ibn Ali, dari Za idah, dari Maisarah, dari Abi Hazim, dari Abu Hurairah ia berkata : Telah besabda Rasulallah saw:

Barangsiapa yang beriman kepada Allah dan hari Akhir, maka apabila ia bersaksi hendaklah ia berkata dengan baik atau diam, Nasehatilah para wanita dengan cara baik, karena wanita diciptakan dari tulang rusuk yang bengkok, dan yang paling bengkok dari tulang rusuk adalah pangkalnya, jika kamu mencoba untuk meluruskannya maka dia akan patah namun bila kamu biarkan maka dia akan tetap bengkok.

\section{Mawarid Zaman Ibnu Hibban}

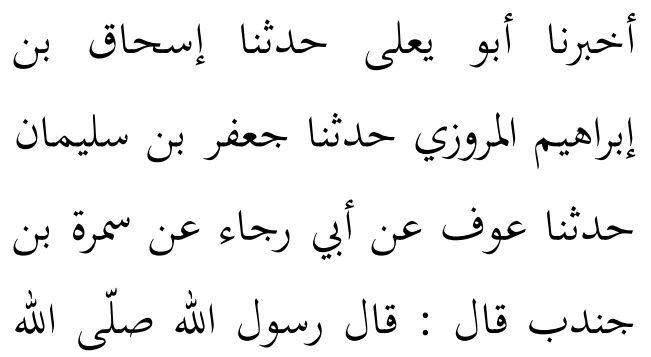

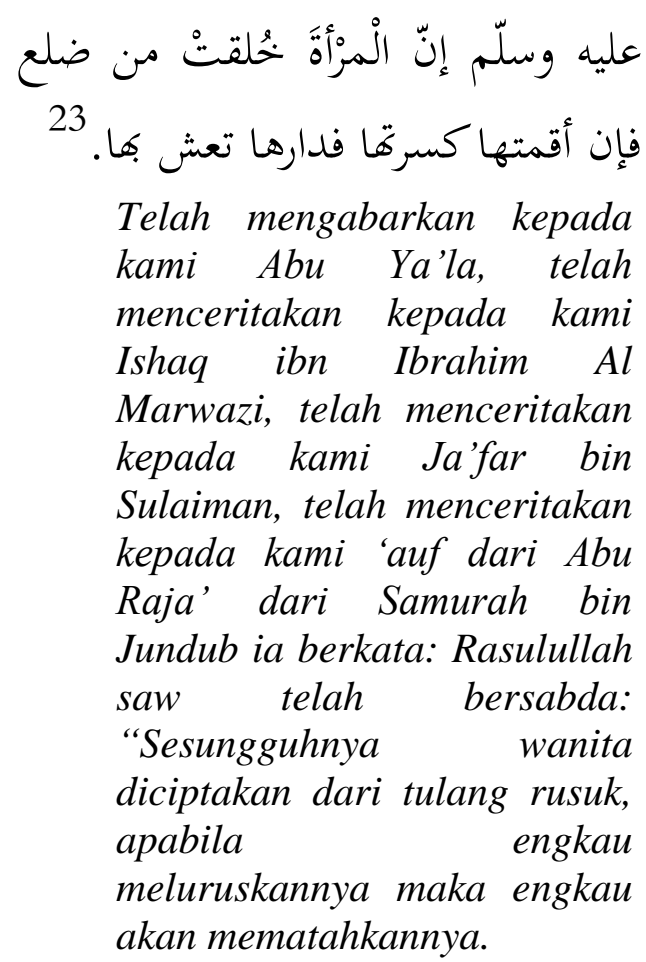

Musnad Al-Humaidi

حَلَّ ثَنَا الْلْمَيْدِي قال, حدثنا سفيان قال حدثنا أبو الزنّاد عن الأعرج عن أبي هريرة قال : قال رسول الله صلّى الله

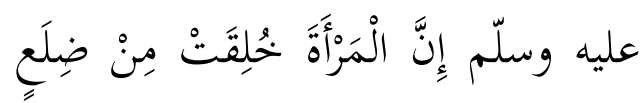

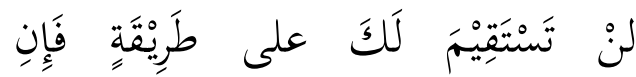
استمتعت بها ,استمتعت بها وفيها عوج وإن ذهبت تقيمها كسرتا, وكسرها طلا قها.

${ }^{23}$ Nūruddīn 'Ali Ibn Abū Bakar alHaitamī, Mawārid al-Zamān ilā Zawāid Ibnu Hibbān (Damaskus: Dārul Ṡaqāfah al'Arabiyyah, 1412 H/1991 M), Juz 1, 247.

${ }^{24}$ Abī Bakar 'Abdillāh Ibn Zubair Al Qurtsiyi al-Humaidi, Musnad Humaidi (Dimasyqi: Dārul Ś̉aqā 1996 M ), Juz 2, 293. 
Telah menceritakan kepada kami Sufyan dia berkata telah menceritakan kepada kami Abu Zinnad dari Al A'raj dari Abu Hurairah dia berkata, Rasulullah saw bersabda : " Sesungguhnya wanita diciptakan dari tulang rusuk, dan tidak dapat kamu luruskan dengan cara bagaimanapun, jika kamu hendak bersenang-senang dengannya, kamu dapat bersenang-senang dengannya dan dia tetap bengkok, namun jika kamu berusaha meluruskannya, niscaya dia akan patah, dan mematahkannya adalah menceraikannya.

\section{Musnad Abu 'Awanah}

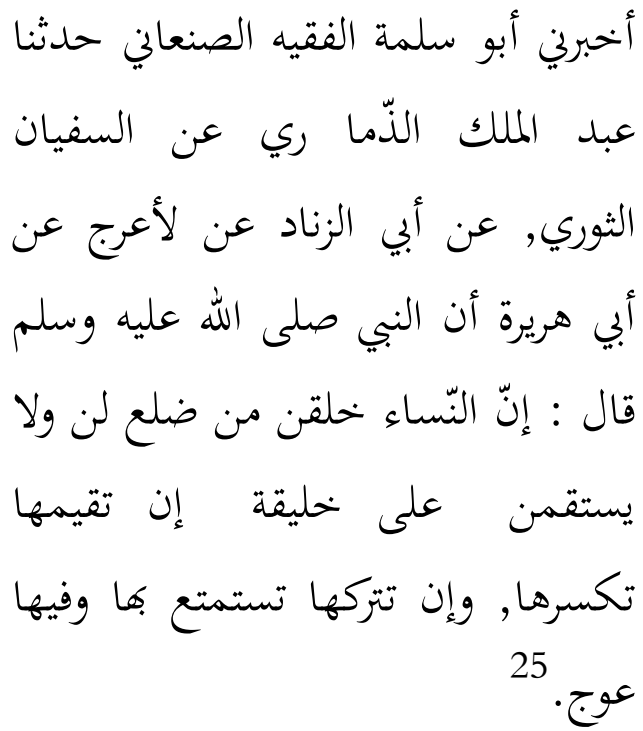

Telah mengabarkan kepadaku Abu Salamah Al-Shan'ani telah menceritakan kepada

${ }^{25}$ Imām Jalīl Abī 'Awānah Ya'qūb bin Ishāa al-Asfirān̄̄,. Musnad $A b \bar{\imath}$ 'Awānah, Taḥqīq Aiman 'Arif Al Dimasyqi (Beirūt : Dārul Ma'rifah, 1419 H / 1998 M), Juz 3, 143. kami Abdul Malik al-Dimari dari Sufyan Al-Tsauri dari Abi Zinnad dari Al-A'raj dari Abu Hurairah bahwasanya Nabi SAW bersabda:" Sesungguhnya perempuan diciptakan dari tulang rusuk, ia tidak bias lurus dalam penciptaannya, jika engkau luruskan maka engkau akan mematahkannya, dan jika engkau biarkan maka ia akan berlaku seperti itu terus, padahal pada diri mereka terkandung unsur bengkok.

\section{Musnad Bazzar}

حدثنا الحسن بن عبد العزيز الجروي قال : حدثنا أيوب ابن سويد الرملي قال: حدثنا يونس عن الزهري عن سعيد عن أبي هريرة قال: قال رسول الله صلّى الله عليه وسلّم إنّ الْمر أة خلقت من ضلع إن ذهبت أن تقيمه, كسرتا وإن تركتها 26

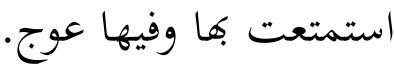

Telah menceritakan kepada kami Hasan ibn Abdul Aziz AlJauri ia berkata: telah menceritakan kepada kami Ayyub ibn Suwaid Al-Ramli ia berkata: telah menceritakan kepada kami Yunus dari Zuhri dari Sa'id Dari Abu Hurairah ia berkata: telah bersada Rasulullah saw:

${ }^{26}$ Imām Abū Bakar Aḥmad ibn 'Umar ibn 'Abdul Khāliq al-'Atiqi alBazzarī, Musnad al-Bazzar. Taḥī̄ 'Adlaban Sa'ad (Madinah: Maktabah 'Ulūm wa al-Hukm, 1427 H /2006 M ), Juz 14, 199. 
"Sesungguhnya wanita diciptakan dari tulang rusuk, jika engkau ingin meluruskannya, maka kamu akan mematahkannya, dan jika kamu biarkan maka ia akan seperti itu terus, padahal pada diri mereka terdapat unsur yang bengkok.

\section{Musnad Al-Harits}

حدثنا هوذة, حدثثنا عوف , عن رجل

قال : سمعت سمرة بن جندب يكطب

على المنبر البصرة وقال : سمعت رسول

الله صلّى الله عليه وسلّم يقول : " إنّ إن

المرأة خلقت من ضلع أعوج, وإنّك إن

تريد إقامة الضلع تكسرها, فدارها تعش

بها فدارها تعش بها .

Telah menceritakan kepada kami Hauzah, telah menceritakan kepada kami 'Auf, dari Rajul ia berkata : aku telah mendengar Samurah bin Jundub berkhutbah di atas mimbar Bashrah dan dia berkata : aku telah mendengar Rasulullah saw bersabda : "aku mendengar Rasulullah saw bersabda:

"Sesungguhnya wanita itu diciptakan dari tulang rusuk kiri, jikalau engkau hendak meluruskan tulang rusuk itu, maka engkau akan

${ }^{27}$ Imām Nūruddīn 'Ali ibn Sulaimān ibn Abū Bakar al-Haișamī alSyāfi'ī, Musnad al-Haris̀ (Madīnah: Jāmi'ah Islāmiyyah, 1413 H / 1992 M ), Juz 1,550 . mematahkannya tapi jika engkau membiarkannya maka ia akan tetap melengkung, jika engkau membiarkannya maka ia akan tetap melengkung.

\section{Musnad Abu Ya'la Al- Mushili}

حدثنا إسحاق بن أبي إسرا ئيل حدثنا حسين بن علي عن زائدة عن ميسرة الأسجعي عن أبي حا زم عن أبي هريرة قال: قال رسول الله صلّى الله عليه وسلّم " من كان يؤ من با الله واليوم لأخر فلا يؤذينّ جاره. من كان يؤمن با الله واليوم الأخر فليحسن قرى ضيفه. قيل يا رسول الله, ما قرى الضيف ؟ " قال : ثلاث فما كان بعد فهو صدقة. من كان يؤمن بالله واليوم

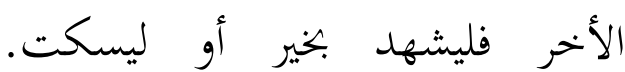
واستوصوا با النّساء خيرا فإنّ الْمرأة خُلِقَتتْ من ضِلَعِ وإِنْ أعوج شيئِ في

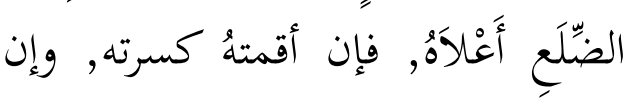
تركته لم يزل أعوجُ واستوصوا با النّساء 28 خيرث.

Telah menceritakan kepada kami Ishaq bin Abi Israil, telah menceritakan kepada kami Husain ibn Ali dari

${ }^{28}$ Aḥmad ibn 'Ali ibn Musanna alTamīmī, Musnad Abū Ya'la al-Mausuli, (Beirūt: Dārul Ma'mūn li al-Turaṡ. 1407 H /1987 M ), Juz 11, 85. 
Zaidah dari Maisarah Al Asja'I dari Abi Hazim dari Abu Hurairah ia berkata : telah bersabda Rasulullah saw: "Barangsiapa yang beriman kepada Allah dan hari akhir maka jangan ia menyakiti tetangganya, barangsiapa yang beriman kepada Allah dan hari akhir berbuat baiklah kepada tamunya. Ada yang bertanya, wahai Rasul tamu yang seperti apa? Rasul menjawab : "tamu yang menginap tiga hari, jika lebih, itu termasuk sedekah, barangsiapa yang beriman kepada Allah dan hari akhir maka berilah kesaksian yang baik atau ia diam. Nasehatilah para wanita dengan cara baik, karena wanita diciptakan dari tulang rusuk yang bengkok, dan yang paling bengkok dari tulang rusuk adalah pangkalnya, jika kamu mencoba untuk meluruskannya maka dia akan patah namun bila kamu biarkan maka dia akan tetap bengkok. Untuk itu nasehatilah para wanita dengan baik.

\section{Sunan Kubra Nasa'i}

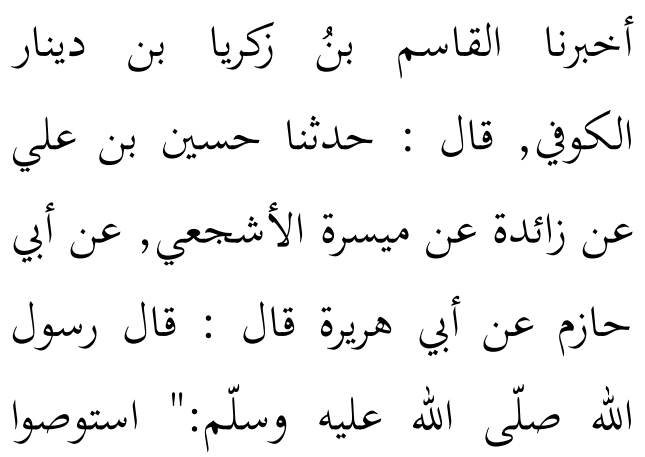

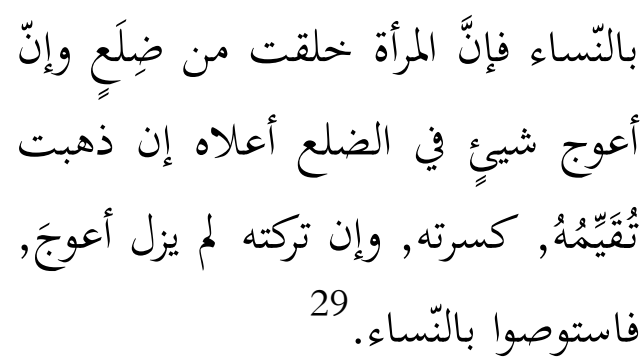

Telah mengabarkan kepada kami Qasim ibn Zakaria ibn Dinar Al-Kufi, ia berkata; telah menceritakan kepada kami Husain ibn Ali dari Zaidah dari Maisarah AlAsyja'i dari ibn Hazim dari Abu Hurairah dia berkata : telah bersabda Rasulullah saw "berwasiatlah kepada wanita, karena sesungguhnya dia diciptakan dari tulang rusuk, dan bagian yang paling bengkok adalah tualng rusuk paling atas, jika kamu berusaha untuk meluruskannya, niscaya akan patah, jika kamu membiarkannya, dia akan senantiasa bengkok, maka berwasiatlah kepada wanita.
${ }^{29}$ Abū Abdul Raḥmān ibn Syu'aib al-Nasā'̄', Sunan Kubrā al-Nasā' ’̄, (Beirūt: Muassasah al-Risālah, 1421 H / 2001 M ), Juz 8, 251. 
APLIKASI TEORI ISNAD CUM MATN HARALD MOTZKI

DALAM HADIS MISOGINIS PENCIPTAAN PEREMPUAN

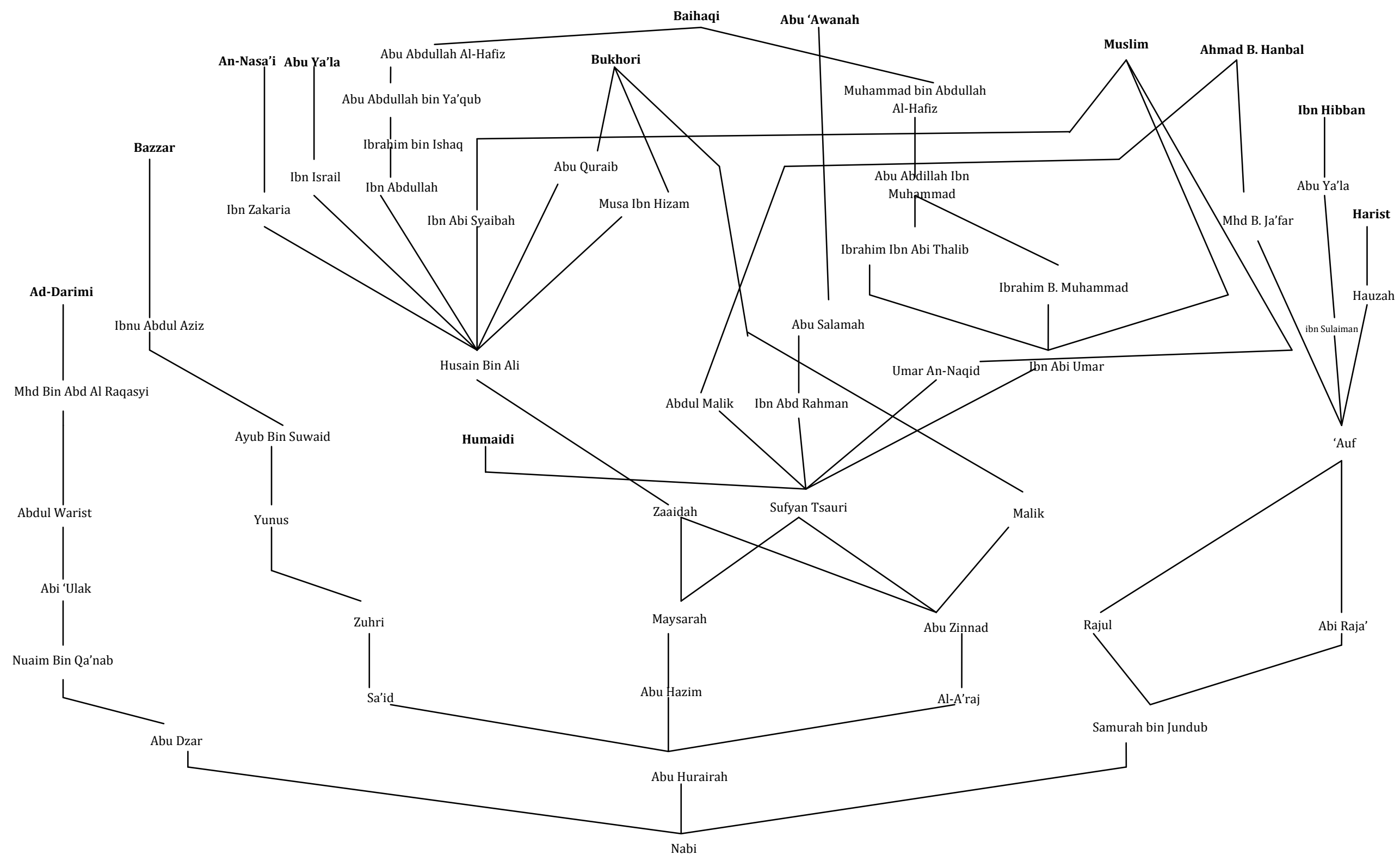

42 Vol. 3, No. 1, Januari - Juni 2020 M/1441 H 


\section{Analisis Isnad Hadis Tentang Penciptaan Wanita dari Tulang Rusuk.}

Ketika hendak melakukan penanggalan hadis menggunakan metode yang disajikan oleh Motzki, maka tidak bisa terlepas dari metode yang di kembangkan oleh Juynboll juga yaitu common link. ${ }^{30}$ Karena di dalam menentukan kapan, siapa, dan di mana sebuah hadis berasal, peneliti dituntut untuk menentukan common link dari sebuah bundle isnad dari hadis yang diteliti. Hadis yang sedang penulis teliti, setidaknya dilaporkan berada di dalam kitab canonical, pra canonical, dan pos canonical. Penulis menemukan hadis yang sedang diteliti di dalam Musnad Ahmad bin Hanbal, Sahih Bukhari, Sahih Muslim, Musnad Bazzar, Sunan Kubra Al-Baihaqi, Musnad Abu 'Awanah, Musnad Abu Ya'la Al-Mushili, Mawrid Zaman Ibn Hibban, Musnad Harits, Sunan Kubra An-Nasa'i, Musnad Humaidi, dan Sunan Ad-Darimi. Menurut metode Juynboll langkah awal yang

\footnotetext{
${ }^{30}$ Kamarudin Amin, Menguji Kembali Keakuratan Metode Kritik Hadits, (Jakarta: Mizan Media Utama, 2009 ), 65.
}

harus dilakukan adalah menentukan siapa yang layak menduduki posisi common link. Untuk melakukan hal tersebut, maka peneliti harus dituntut untuk menganalisis secara luas bundle isnad yang ada.

Berdasarkan diagram di atas dapat diketahui bahwa setidaknya ada tiga orang sahabat yang menerima hadis tentang penciptaan wanita dari tulang rusuk. Mereka adalah Abu Hurairah, Samurah bin Jundub, dan Abu Dzar. Namun, lebih jauh bila dilihat bahwa yang berperan dalam penyebaran hadis ini adalah Abu Hurairah, karena telah membangun sebuah bundle isnad yang luas dalam penyebaran hadis penciptaan wanita dari tulang rusuk.

\section{Jalur Sufyan Al-Tsauri}

Sahabat Abu Hurairah (w. $678 \mathrm{M}$ ) telah meriwayatkan kepada tiga orang yang diduga sebagai muridnya. Mereka adalah Al-A'raj, Abu Hazim, dan Sa'id. Masingmasing dari mereka kemudian meriwayatkan kepada satu murid. Kemudian tiga orang yang diduga sebagai murid Abu Hurairah ini, kemudian meriwayatkan kepada 
masing-masing satu muridnya, yaitu Abu Zinnad, Maysarah dan Zuhri. Kemudian dua jalur, yakni jalur Abu Zinnad dan Maysarah sama-sama meriwayatkan hadis kepada dua orang yang juga diduga sebagai murid mereka, yaitu Sufyan AlTsauri dan Zaaidah, akan tetapi Abu Zinnad selain meriwayatkan kepada dua orang di atas, ia juga meriwayatkan kepada Malik. Dimulai dari Sufyan periwayatan hadis penciptaan wanita dari tulang rusuk ini berkembang kepada lima murid yakni : Humaidi, Ibn Abdul Rahman, Abdul Malik, Umar AnNaqid dan Ibn Abi Umar. Adapun varian hadis yang sedang diteliti yang di laporkan oleh Sufyan AlTsauri direkam di dalam sejumlah sumber yaitu : Musnad Ahmad bin Hanbal, Sahih Muslim, Sunan AdDarimi, Musnad Abu 'Awanah, Sunan Kubra Baihaqi, dan Musnad Al-Humaidi. Sufyan Al-Tsauri sebagai seorang perawi mempunyai posisi yang sangat berpengaruh di dalam penyebaran hadis ini, maka pertanyaan yang kemudian harus dijawab adalah apakah Sufyan AlTsauri menempati posisi the real
Common link di dalam periwayatan hadis penciptaan wanita dari tulang rusuk. Untuk menjawab pertanyaan di atas maka kita harus menganalisis jalur-jalur periwayatan yang disandarkan kepada orang yang di duga sebagai pupill murid dari Sufyan Al-Tsauri.

\section{Jalur Humaidi ( 155-219 H )}

Uraian yang akan dianalisis pertama adalah jalur periwayatan Humaidi. Al-Humaidi langsung mengambil hadis tersebut dari Sufyan Al-Tsauri. maka kemudian jalur yang dari Al-Humaidi adalah jalur tunggal atau apa yang disebut oleh Juynboll sebagai singel strand.

\section{Hadis Abdul Malik Ibn Abdul Rahman Ad-Dimari}

Murid Sufyan Al-Tsauri yang telah meriwayatkannya darinya adalah Abdul Malik ibn Abdul Rahman Ad-Dimari. Dilaporkan bahwa hanya satu jalur yang kembali kepada Sufyan Al-Tsauri melalui Ibn Abdul Rahman Ad-Dimari yaitu Ahmad bin Hanbal. Dan ini juga di sebut oleh Juynboll sebagai jalur singel strand. Kemudian murid 
lainnya adalah Abdul Malik yang terdapat satu jalur yang menjadi singel strand yang direkam oleh Abu 'Awanah melalui Abu Salamah. Begitu juga dengan jalur yang di ajukan oleh Muslim tanpa murid dan hanya berjalur tunggal. Murid Sufyan selanjutnya adalah Umar AnNaqid yang direkam oleh Muslim, juga merupakan satu jalur tanpa murid dan lansung diriwayatkan Muslim dari Umar An-Naqid. Periwayatan selanjutnya adalah periwayatan dari Ibn Abi Umar. Berdasarkan isnad, Ibn Abi Umar menyebarkan hadis ke beberapa muridnya, yakni Muslim, Ibrahim bin Muhammad, dan Ibrahim bin Abi Thalib. Yang direkam oleh Baihaqi melalui Muhammad bin Abdullah Al-Hafiz. Oleh karenanya, Ibn Abi Umar hanya disebut sebagai seeming partial common link. Dengan demikian, bundle isnad Sufyan Al-Tsauri di sebut spider karena dikelilingi empat jalur singel strand dan satu jalur seeming partial common link.

\section{Jalur Zaaidah}

Dilihat dari bundle isnad, jalur yang berpengaruh terhadap penyebaran hadis ini selanjutnya adalah jalur Zaaidah, yang kemudian dia meriwayatkan kepada satu orang yang di duga muridnya, yaitu Husain bin Ali. Kemudian dari Husain lah kemudian hadis ini menyebar dan direkam setidaknya empat kolektor yaitu An-Nasa'i, Abu Ya'la AlMushili, Bukhari, dan Baihaqi. Apakah kemudian Husain bisa di katakan the real common link. Untuk menjawab pertanyaan tersebut maka kita akan menganalisis jalur yang menyebar dari Husain Ibn Ali yang kemudian berakhir di dalam beberapa kitab hadis. Husain bin Ali dilaporkan telah menyebarkan hadis yang sedang diteliti tidak kurang dari enam orang yang diduga muridnya, yaitu Musa Ibn Hizam, Abu Quraib, Abu Bakar bin Abi Syaibah, Harun bin Abdullah, Ishaq bin Abi Israil dan Qasim bin Zakaria.

Hadis yang kemudian diriwayatkan oleh Abu Quraib dan Musa ibn Hizam langsung mereka riwayatkan kepada Bukhari yang seolah-olah kelihatan sebagai 
inverted common link dari Bukhari. Kemudian hadis yang diriwayatkan oleh Abu Bakar bin Abi Syaibah adalah jalur tunggal yang langsung diterima oleh Muslim tanpa melalui perantara. Kemudian perawi yang diduga sebagai murid Husain bin Ali adalah Harun bin Abdullah. Hadis yang diriwayatkan oleh Harun bin Abdullah adalah jalur tunggal atau singel strand yang direkam oleh Baihaqi melalui Ibrahim bin Ishaq, Abu Abdillah bin Ya'qub, Abu Abdullah Al Hafiz. Jalur yang diriwayatkan oleh Ishaq bin Abi Israil adalah jalur singel strand yang langsung diterima oleh Abu Ya'la Al-Mushili. Begitu juga dengan jalur yang diriwayatkan oleh Qasim bin Zakaria juga singel strand yang langsung di ambil oleh An-Nasa'i. Menurut metode Juynboll maka jalur yang kemudian menyebar dari Husain bin Ali ini disebut sebagai spider. Karena ia dikelilingi oleh 4 singel strand dan 1 inverted common link.

Selain Abu Hurairah, sahabat lain yang juga meriwayatkan hadis yang sedang diteliti adalah Samurah bin Jundub. Dilihat dari bundel isnad, Samurah bin Jundub meriwayatkan hadis yang sedang di teliti kepada dua orang sebagai muridnya yakni, Rajul dan Abi Raja'. Dua muridnya ini kemudian meriwayatkan kepada satu murid yaitu 'Auf. Dari 'Auf kemudian hadis ini terekam di dalam Musnad Ibnu Hanbal melalui Muhammad bin Ja'far, kemudian tertulis di dalam Mawarid Ibnu Hibban melalui Abu Ya'la Al-Mushili, kemudian terekam di dalam Musnad Harits melalui Hauzah. Jika diterap metode Juynboll di dalam menentukan seorang periwayat yang bisa disebut sebagai common link, sekiranya Samurah bin Jundub lebih tepat di sebut sebagai seeming common link. Sahabat lain yang menerima hadis yang sedang diteliti, adalah Abu Dzar. Menurut Juynboll jalur yang direkam oleh Ad-Darimi melalui Nua'im bin Qa'nab, Abi Ulak dan Muhammad bin Abdullah AlRaqasyi, di sebut sebagai singel strand.

Dilihat dari bundle isnad, kalau kita terapkan metode Juynboll secara kaku untuk menentukan seorang common link, maka dapat 
disimpulkan di dalam bundle isnad hadis yang diteliti tidak ada seorang periwayat yang menjadi common link. Ini merupakan kesimpulan yang naif dan sangat tidak bijaksana. Penulis mencoba menerapkan teori Harald Motzki dan Powers untuk mencari seorang common link. Di sini dapat penulis simpulkan bahwa yang pantas menjadi common link dari hadis yang sedang diteliti adalah Nabi sendiri, karena kiranya hadis yang sedang dikaji telah menyebar dari Nabi kepada beberapa sahabat.

Pembahasan sebelumnya telah diketahui siapa yang menjadi common link di dalam hadis yang sedang diteliti, maka selanjutnya akan diteliti adalah matan dari hadis tersebut. Hasil dari analisis isnad harus dikonfirmasi kembali melalui analisis matan, karena untuk bisa merengkuh historisitas sebuah hadis diharuskan untuk dapat mencapai semua aspek di dalam hadis itu sendiri. Dalam hal ini adalah sanad dan matan. ${ }^{31}$ Analisis matan di lakukan pada penciptaan wanita dari tulang rusuk secara keseluruhan,

\footnotetext{
${ }^{31}$ Kamarudin Amin, Menguji Kembali Keakuratan Metode Kritik Hadis, 253.
}

namun untuk mempermudah pembahasan, maka analisis matan dilakukan mulai dari matan-matan yang dalam periwayatan common link, kemudian akan di lanjutkan dengan matan dalam jalur-jalur lainnya seperti spider, dan singel strand.

\section{Analisis Matan Jalur Al-A'raj}

Nabi menyampaikan hadis yang sedang diteliti kepada tiga orang sahabat yaitu Abu Hurairah, Samurah bin Jundub, Abu Dzar. Di dalam bundel isnad yang dibangun, hadis yang sedang dibahas setidaknya terekam di dalam 12 kitab hadis yakni Sahih Bukhari, Sahih Muslim, Musnad Ahmad bin Hanbal, Musnad Humaidi, Musnad Abu Awanah, Sunan Kubra Baihaqi, Sunan Kubra An-Nasa'i, Sunan AdDarimi, Musnad Abu Ya'la 1Mushili, Musnad Bazzar, Musnad Harist, dan Mawarid Ibnu Hibban. Berdasarkan kitab yang tersedia di dalam periwayatan ini, maka Musnad Ahmad bin Hanbal adalah yang paling tua di antara 11 kitab lainnya dan akan menjadi patokan 
analisis matan pada hadis yang sedang diteliti.

Secara keseluruhan, konten dari hadis-hadis yang disampaikan di dalamnya mempunyai persamaan makna, walaupun terdapat beberapa perbedaan dalam penggunaan katakatanya secara literal, seperti istilah tahammul wa al-ada', seperti AlA'raj memakai kata 'an untuk Abu Hurairah sedangkan Rajul memakai kata Sami'tu untuk Samurah Bin Jundub. Kemudian konten matannya, hadis yang diriwayatkan oleh AlA'raj melalui Abu Hurairah memakai kata Inna Nisa-a untuk permulaan matan sedangkan di dalam jalur yang disampaikan oleh Rajul yang melalui Samurah memakai kata Inna al Mar'ata untuk permulaan matan hadis. Kemudian pada hadis yang diriwayatkan oleh Abu Hurairah, ia memakai kata Anna al-nabiyya, pada jalur Samurah bin Jundub memakai kata Sami'tu untuk Rasulullah.

Dikarenakan yang menjadi common link di dalam penelitian ini adalah Nabi Muhammad Saw, maka penulis harus melihat matan dari jalur lain, selain daripada jalur matan yang direkam oleh Ahmad Ibn Hanbal. Di dalam hadis yang sedang diteliti, setidaknya ada dua jenis hadis tentang awal penciptaan perempuan ini. Pertama, hadis yang matannya panjang dan hadis yang matannya pendek. Hadis yang matannya panjang setidak terdapat di dalam beberapa jalur yaitu jalur yang disuguhkan oleh Baihaqi melalui țruq Abu Hurairah, kemudian Muslim juga melalui Abu Hurairah, dan Abu Ya'la Al-Mushili melalui Abu Hurairah. Jika dilihat dari segi matan, hadis yang mempunyai matan yang panjang ini sebenarnya sama maksudnya, tetapi ada beberapa kalimat yang berbeda di antara ketiga periwayat yang merekam matan tersebut.

Di dalam matan yang direkam oleh Abu Ya'la terlihat ada beberapa tambahan kalimat seperti setelah kalimat كان يؤ من با الله واليوم الأ خر di dalam matan yang di rekam oleh Abu Ya'la مuga terlihat kalimat من كان يؤ من با الله gi sebutkan dua kali. Pertama di bagian awal matan hadis, dan yang kedua disebutkan di pertengahan matan hadis. 
Selanjutnya di dalam matan yang direkam oleh Abu Ya'la juga terlihat penambahan kalimat مثلاث فما كان بعد

فهو صدقة dan pada akhir matan hadis yang direkam olehnya beliau واستوصوا kalimat , بالنساء خيرا, meskipun di pertengahan matan yang direkam olehnya, beliau juga menyebutkan kalimat yang sama. Agaknya penambahan ini dikarena Abu Ya'la ingin mempertegas kalimat yang sama yang ditulis sebelumnya.

Berbeda dengan matan hadis yang direkam oleh Muslim dan Baihaqi, nampak hampir tidak ada perbedaan yang mencolok. Hanya saja di akhir matan Baihaqi penambahan huruf فntuk kalimat وذهبت تقيمه riwayat Muslim tidak memakai huruf (Fa). Perbedaan yang terakhir adalah, di dalam hadis yang diriwayatkan oleh Baihaqi, pada akhir matan tidak memakai kalimat sedangkan di dalam riwayat Muslim kalimat tersebut ditambahkan di akhir matan.

Dengan demikian, matan yang direkam oleh ketiga periwayat di atas yaitu Abu Ya'la Al-Mushili,
Baihaqi, dan Muslim mempunyai kesamaan konten walaupun ada beberapa perbedaan penulisan matan.

\section{Matan Hadis Sufyan Al-Tsauri.}

Sufyan al-Tsauri adalah seorang Tabi'in yang menerima hadis dari Abu Hurairah melalui Abu Zinnad dan Al-A'raj. Sufyan telah menyampaikan hadis yang diterimanya dari Abu Hurairah melalui dua periwayat yang penulis sebutkan di atas kepada tidak kurang dari lima orang yang diduga muridnya. Mereka adalah Humaidi, Ibn Abdul Rahman, Abdul Malik, Umar An-Naqid dan Ibn Abi Umar. Hadis yang di riwayatkan oleh Sufyan ini terekam di dalam lima kitab hadis yaitu, Musnad Humaidi, Musnad Ahmad Bin Hanbal, Mushannaf Abu 'Awanah, Sunan Kubra Baihaqi, dan Sahih Muslim. Secara keseluruhan, apabila dilihat, hadis yang diterima oleh murid Sufyan Al-Tsauri sebenarnya terdapat kesamaan. Namun, menarik untuk dilihat bahwa kemudian Sufyan menyampaikan hadis yang sedang diteliti ini kepada muridnya 
dengan dua versi. Versi pertama yang direkam oleh Humaidi, Baihaqi dan Muslim mempunyai matan yang persis sama. Dan versi kedua yaitu matan yang diterima oleh $\mathrm{Abu}$ 'Awanah dan Ahmad bin Hanbal juga persis sama. Di dalam matan Humaidi, Baihaqi dan Muslim mereka memakai hadis yang diawali dengan kata انّ المرأة خلقت من ضلع, dengan tambahan kata عوج di akhir matan hadis. Kemudian hadis yang diterima oleh $\mathrm{Abu}$ 'Awanah dan Ahmad bin Hanbal, diawali dengan lafaz انّ النساء خلقن من ضلع dan di akhiri dengan kalimat وفيها عوج.

Dengan demikian dari analisis matan, terdapat beberapa jalur yang kembali kepada Sufyan Al-Tsauri dan mempunyai kesamaan konten. Dan ternyata Sufyan AlTsauri menyampaikan dua versi hadis kepada muridnya yang terekam dalam beberapa kitab hadis di antaranya Sahih Muslim, Sunan Kubra Baihaqi, Musnad Abu 'Awanah, Musnad Ahmad bin Hanbal, dan Musnad Humaidi. Dan kontennya mempunyai kesamaan yang menyebutkan bahwa asal mula penciptaan perempuan dari tulang rusuk, yakni matan Humaidi, Ibn Abdul Rahman, Ibn Abi Umar, Ibrahim bin Muhammad, Ibrahim bin Abi Thalib Abu Abdillah Ibnu Muhammad, Muhammad bin Abdullah Al-Hafiz, dan Umar AnNaqid dalam versi pertama. Sedangkan versi kedua matan yang direkam oleh Ibnu Abdul Rahman, Abdul Malik, dan Abu Salamah yang tidak memakai kata Thalaqaha pada akhir matan hadis yang mereka terima. Sedangkan jalur yang direkam oleh Bukhari melalui Malik dan Abu Zinnad juga mempunyai kesamaan konten dengan hadis yang direkam oleh Ahmad bin Hanbal dan Abu 'Awanah melalui Ibnu Abdul Rahman, Abdul Malik, dan Abu Salamah. Hanya saja matan yang direkam oleh Bukhari ini mengalami penambahan di awal matannya dengan kalimat استوصوا بالنساء. Sedangkan di dalam hadis Ahmad bin Hanbal, Abu Awanah tidak memakai lafaz tersebut.

\section{Jalur Zaidah}

Zaidah merupakan salah satu periwayat hadis yang sedang di teliti ini. Dilihat lebih jauh hadis yang 
diterima oleh Zaidah dari Abu Hazim melalui Maysarah, kemudian ia sampaikan kepada seorang yang di duga muridnya yaitu Husain ibn Ali. Dari Husein inilah kemudian hadis ini menyebar dan terekam di dalam beberapa kitab hadis, yaitu Sahih Bukhari, Sahih Muslim, Sunan Kubra Baihaqi, Musnad Abu Ya'la, dan Sunan Kubra Nasa'i. Hadis yang kemudian disampaikan oleh Husein melalui Zaidah, terpantau memiliki dua versi. Versi ini bisa dikatakan dengan versi panjang dan pendek. Untuk versi panjangnya di awali dengan lafaz من كان يؤ من با الله واليوم الأ خر. Ini diterima oleh Muslim melalui Ibn Abi Syaibah, Abu Ya'la melalui Ibnu Israil, dan Baihaqi melalui Abu Abdullah bin Ya'qub, Abu Abdullah Al-Hafiz, Ibrahim bin Ishaq dan Ibn Abdullah. Sedangkan dalam versi pendeknya direkam oleh Bukhari melalui Abu Quraib dan Musa Ibn Hizam dan Nasa'i melalui Ibn Zakaria dan Husein bin Ali استوصوا بالنساء dengan memakai lafaz pada awal matan hadisnya.

Pada dasarnya matan hadis yang diterima oleh beberapa kolektor hadis ini memiliki kemiripan masing-masing. Yang versi panjangnya sangat mirip begitupun yang versi pendeknya.

\section{Jalur Sa'id}

Jalur yang direkam oleh Sa'id ini adalah jalur single strand yang berakhir di dalam kitab musnad Bazzar. Dilihat dari matan hadis yang direkam di dalam periwayatan ini, tampak lebih pendek daripada matan yang diriwayatkan oleh Humaidi, Baihaqi dan Muslim. Tetapi meskipun demikian, matan yang direkam oleh Bazzar ini memiliki kesamaan dalam makna yang dikehendaki dari hadis yang sedang diteliti ini. Meskipun di dalam matan yang disuguhkan Bazzar tampak lebih pendek dan simple. Adapun matan di dalam إنّ الْمر أة kitab Musnad Bazzar adalah خلقت من ضلع إن ذهبت أن تقيمه, كسرتها وإن تركتها استمتعت بها وفيها عوج.

\section{Jalur Abu Dzar}

Selain Abu Hurairah, sahabat yang menerima hadis yang ini langsung dari Rasulullah Saw adalah Abu Dzar. Memang benar bahwa Rasulallah Saw menyampaikan hadis 
ini kepada tiga orang sahabat. Jika dilihat dari sanad, sebagai mana yang telah penulis sebutkan di atas, bahwa jalur yang membentang dari Nabi Muhammad Saw sampai kepada kolektor hadis, dalam hal ini adalah imam Ad-Darimi, maka jalur ini disebut sebagai Single Strand sebagaimana yang telah dirumuskan oleh Juynboll. Namun, apabila di lihat dari sisi matan, hadis yang disampaikan oleh Abu Dzar yang kemudian direkam oleh Ad-Darimi di dalam kitab sunannya, memiliki kesamaan dari segi konten dengan hadis yang direkam oleh Imam Bukhari. Tetapi, hadis yang direkam oleh Imam Ad-Darimi ini memiliki beberapa perbedaan dengan apa yang diterima oleh Imam Bukhari dari Husein bin Ali melalui Abu Quraib dan Musa Ibn Hizam dan Abu Zinnad melalui Malik.

Perbedaannya terlihat di akhir matan hadis yang di terima oleh Imam Ad-Darimi dari Abdul Wasit melalui Muhammad Ibn Abdul Al-Raqasy yaitu فَفَارِها فَاِنَّ فَيْها أوََدَ وَيَنْغَةً , sedangkan di dalam hadis yang direkam oleh Imam Bukhari tidak memakai kalimat ini.

\section{Jalur Samurah bin Jundub}

Sahabat lain yang menerima hadis ini dari Nabi langsung adalah Samurah bin Jundub. Tercatat bahwa hadis yang sedang diteliti, diriwayat oleh Samurah bin Jundub terekam di dalam beberapa kitab hadis kanonik maupun post kanonik, di antaranya adalah musnad Ahmad bin Hanbal, Musnad Al-Harits, dan Mawarid Ibnu Hibban. Jika ditelusuri lebih jauh, matan yang sampai kepada masing-masing kolektor dari Samurah bin Jundub ini sebenarnya sama dengan hadis yang direkam oleh periwayat-periwayat lain, seperti Abu Awanah, dan Baihaqi. Hanya saja di dalam matan hadis yang direkam oleh Ahmad bin Hanbal dari 'Auf melalui Muhammad bin Ja'far, memakai lafaz فدارها تعش بها, sedangkan di beberapa riwayat lain memakai kalimat yang berbeda di akhir matan hadis ini. Namun, perbedaan pemakaian lafaz di dalam beberapa riwayat tidak mempengaruhi makna dari hadis tersebut. 
Kemudian hadis yang atas penyebaran hadis di atas adalah direkam oleh Ibnu Hibban di dalam kitabnya melalui Abu Ya'la, sama persis dengan hadis yang direkam oleh Bukhari di dalam Sahihnya. Jadi penulis rasa tidak perlu memapar ulang tentang hadis riwayat Ibnu Hibban ini. Kolektor lain hadis ini dari Samurah bin Jundub adalah Ahmad bin Hanbal.

\section{Kesimpulan}

Dari penjelasan di atas dapat penulis simpulkan bahwa di dalam pengkajian terhadap hadis misoginis terutama hadis yang menceritakan asal mula penciptaan perempuan, dilihat dari sisi sanad maka yang menjadi common link atau orang yang bertanggung jawab Nabi Muhammad SAW. Ini dapat di lihat dari adanya tiga orang sahabat yang menerima hadis ini langsung dari Nabi yaitu Abu Hurairah, Samurah bin Jundub dan Abu Dzar. Selanjutnya dilihat dari sisi matan maka hadis ini mempunyai dua matan yaitu matan panjang dan matan pendek. Nampaknya orang yang berpengaruh dengan tersebarnya matan ini adalah Nabi sendiri karena Nabi ketika menyampaikan kepada masingmasing sahabat telah memperlihat dua versi yang berbeda. Serta diperkirakan hadis ini muncul pada akhir abad 1 Hijriyyah serta awal abad ke-2 Hijriyah.

\section{Daftar Pustaka}

al-Andalusīe, Muhallab ibn Ab̄̄ Șafrah al-Tamimī al-Mālikī. Mukhtaṡar al-Nasih fì Taḥzīb al-Kitāb Jāmi’ al-Saḥịh, Muḥaqqiq Aḥmad Ibn Faris al-Salumī. Riyaụ: Dārul Tauḥ̄i, Dārul Ahli Sunnah, 1430 H / 2009 M.

Ali, Masrur. Teori Common link G.H. A. Juynboll Melacak Akar Kesejarahan Hadis Nabi. Yogyakarta : LKiS, 2007.

al-Asfirānī, Imām Jalīl Ab̄̄ 'Awānah Ya'qūb bin Isḥāq. Musnad Abī 'Awānah, Taḥqīq Aiman 'Arif al-Dimasyqi. Beirūt: Dārul Ma’rifah, 1419 H / 1998 M. 
al-Bazzarī, Imām Abū Bakar Aḥmad ibn 'Umar ibn 'Abdul Khāliq al-'Atiqi. Musnad al-Bazzar. Taḥqīq 'Adlaban Sa'ad. Madinah: Maktabah 'Ulūm wa al-Hukm, 1427 H /2006 M.

al-Bukhārī, Abū 'Abdillāh Muḥammad bin Ismā'īl ibn Ibrāhīm ibn Mughīrah al Ju'fi. Jam'u Al Sahih. T.t: Dārul Tuqi al-Najāḥ, 1422 H.

al-Baihaq̄̄, Abū Bakar Aḥmad bin Ḥusain ibn 'Ali. Sunan Al-Kubrā al-Baihaqī. Beirūt: Dār al-Kitāb al-Alamiyyah, 1424 H/ 2003 M.

Dadah, "Metode Kritik Matan Hadis Misoginis Menurut Fatimah Mernissi, Diroyah: Jurnal ilmu Hadis 3, 1 September 2018.

al-Dārimī, Abū Muḥammad 'Abdullāh ibn 'Abdurrahmān ibn Faḍil ibn Bahram, Sunan al-Dārimī. T.t : Darul Mughni, 1421 H /2000 M.I

Fatima, Mernissi. Wanita Dalam Islam. Bandung: Pustaka, 1414 H/ 1994 M.

Al-Haitamī, Nūruddīn 'Ali Ibn Abū Bakar. Mawārid al-Zamān ilā Zawāid Ibnu Hibbān. Damaskus: Darul Saqafah al-'Arabiyyah, 1412 H/1991 M.

al-Humaidi, Ab̄̄ Bakar 'Abdillāh Ibn Zubair al-Qurtsiyi. Musnad Humaidi. Dimasyqi: Darul Tsaqa 1996 M.

Kamarudin, Amin. Menguji Kembali Keakuratan Metode Kritik Hadis. Jakarta: Mizan Media Utama, 2009.

Muhtador, Muh “ Memahami Hadis Misoginis Dalam Perspektif Hermeneutika Produktif Hans Gadamer” di dalam Jurnal Diya al-Afkar Vol.6 No. 2, Desember 2018.

al-Nasa'i, Abi Abdul Rahman ibn Syu'aib. Sunan Kubra An Nasa'i. Beirut: Muassasah Al Risalah, 1421 H / 2001 M.

al-Naysābūrī, Abū Ḥusain Muslim bin Hajjāj al-Qusyairy. Sahih Muslim. Beirut: Dar Al-Kitab Al Alamiyyah 1412 H / 1991 M.

Nurun, Najwah. Rekonstruksi Pemahaman Hadis- hadis Perempuan, Disertasi Doctor IAIN Sunan Kalijaga Yogyakarta 2004.

Rona, Rasyidaturrabi'ah. Hadis Nikah Mut'ah (Studi Aplikatif Isnad cum matn), Skripsi Fakultas Ushuluddin UIN Sunan Kalijaga Yogyakarta 2015. al-Syabaini, Abū 'Abdillāh Aḥmad bin Mụ̣ammad bin Ạ̣mad bin Hilal bin Asad bin, Musnad Aḥmad bin Hanbal. T.t: Muassah Aal-Risālah, T.t.

al-Syāfi'‘̄', Imām Nūruddīn 'Ali ibn Sulaimān ibn Abū Bakar al-Haiṡamī. Musnad Al Haris̀. Madīnah: Jāmi‘ah Islīmiyyah, 1413 H / 1992 M. 
al-Tamīmī, Aḥmad ibn 'Ali ibn Mutsanna. Musnad Abū Ya'la Al Mausuli. Beirūt: Dārul Ma’mūn li al-Turaṡ. 1407 H /1987 M.

https://www.academia.edu/29873602/Otentisitas_Hadis_Penelusuran_Harald_Mo tzki_terhadap_Mushannaf_Abdul_Razzq, diakses pada tanggal 4 April 2019. 